\title{
PENTINGNYA MELESTARIKAN BAHASA DAERAH
}

\author{
Joleha Nacikit
}

\begin{abstract}
Absract
Regional languages in Indonesia have different characteristics and characteristics from one language to another. The uniqueness of the language of each region signifies the identity of a particular region, so it is important to conduct a study that can clearly demonstrate the uniqueness. That needs to be the main concern, because most in calling languages one another are different languages or just differences in variation, it is not yet clear. Each region does not want the language to be equated with languages in other regions. Most Indonesians make local languages their mother tongue. In addition, it also functions as a cultural language, an intra-ethnic unifying language, strengthening intimacy and for knowing the history and evidence of ancestral heritage in the form of spoken devices. Regional languages play an important role as identity, characteristics, communication tools, and instruments for centuries to thousands of years through oral and written. Luckily for children born to families who are accustomed to regional languages in their daily activities at home. For example, the two parents are the banda and the Javanese.
\end{abstract}

Keyword: languages, Indonesian, Cultural. 
Bahasa-bahasa daerah yang ada di Indonesia memiliki ciri dan karakteristik yang berbeda antara satu bahasa dengan bahasa yang lain. Keunikan bahasa setiap daerah menandakan identitas daerah tertentu, sehingga penting untuk dilakukan suatu kajian yang dapat dengan jelas menunjukkan keunikan tersebut. Hal itu perlu menjadi perhatian utama, karena kebanyakan dalam menyebut bahasa yang satu dengan yang lain merupakan bahasa yang berbeda atau hanya perbedaan variasi, belumlah jelas. Masing-masing daerah tidak ingin bahasanya disama-samakan dengan bahasa di daerah yang lain (S, Susiati, 2019).

Kekayaan luar biasa yang tanpa kita sadari perlahan lenyap dan punah di negeri ini. Yaitu bahasa daerah. Bahasa daerah adalah kekayaan terakhir sebuah bangsa sebagai bukti adanya peradaban, seni dan budaya bahkan eksistensi bangsa itu sendiri yang diwariskan baik secara lisan maupun tulisan. Kondisi terancamnya bahasa daerah mendorong Badan Unesco PBB menetapkan tanggal 21 Februari sebagai hari bahasa daerah internasional. Menurut data Organisasi Pendidikan, Keilmuan dan Kebudayaan PBB (Unesco: United Nations Education, Social and Culture Organization) pada 2014 menyebutkan bahwa sebanyak 3000 dari 6000 bahasa di dunia hampir punah, sebagian besar milik etnis minoritas (Republika, 24/9/14). Menurut Direktur Unesco Sheldon Shaefffer bahwa 96 persen dari bahasa yang hampir punah (3000 bahasa) itu hanya digunakan oleh 4 persen populasi dunia. Lebih parahnya menurut data dari Ethnologue Languages of the World melaporkan bahwa untuk kawasan Asia Tenggara terdapat 527 bahasa terancam hampir punah. Sedangkan di Indonesia menurut hasil penelitian Lembaga Ilmu Pengetahuan Indonesia (LIPI) bahwa dari 746 bahasa daerah yang ada di tanah air sebanyak 169 bahasa terancam punah dengan kondisi jumlah penutur di bawah 500 orang, sudah tua-tua serta tidak ada generasi muda pengganti dan berada di lokasi terpencil.

Fungsi Bahasa Daerah.

Sebagian besar masyarakat Indonesia menjadikan bahasa daerah sebagai bahasa ibu. Di samping itu ia juga berfungsi sebagai bahasa budaya, bahasa pemersatu intra-etnis, mempererat keakraban serta untuk mengetahui sejarah dan bukti peninggalan nenek moyang dalam bentuk perangkat bertutur. Bahasa daerah memegang peranan penting sebagai indentitas, ciri khas, alat komunikasi, dan instrument selama berabad-abad hingga ribuan tahun lewat lisan dan tulisan. Beruntung bagi anak yang lahir dari keluarga yang membiasakan berbahasa daerah dalam aktivitas sehari-hari di rumah. Misalnya kedua orantuanya suku Batak Mandailing dan berbicara Bahasa Batak Mandailing dalam keseharian, otomatis anaknya akan lancar, fasih dan paham aturan budaya, adat dan seni dalam suku Mandailing. Begitu pula yang 
suku Jawa, Melayu, Aceh, Karo dan lain-lain. Ketika si anak tumbuh besar, dia tidak saja menguasai bahasa daerah yang diterimanya di rumah dan lingkungan sosial masyarakat, tetapi juga akan fasih menguasai Bahasa Indonesia sebagai bahasa nasional yang didapat di bangku sekolah TK, SD, SMP, SMA hingga perguruan tinggi.

Jadi, sangat dianjurkan bagi para orangtua untuk membiasakan anak berkomunikasi dengan bahasa daerah. Jangan pernah takut atau khawatir anak akan gagap berbahasa Indonesia gara-gara sejak kecil lebih dibiasakan bahasa daerah, karena lambat laut si anak akan cepat belajar bahasa Indonesia di lingkungan sosial sekolah dan masyarakat. Sangat disayangkan kadangkala ada anak memiliki marga Batak, tetapi tidak bisa bahkan tidak tahu bahasa daerahnya sendiri. Juga ada siswa atau mahasiswa mengaku bersuku Jawa tetapi sama sekali tidak bisa memahami apalagi menuturkan Bahasa Jawa baik Kromo maupun Ngoko. Begitu pula yang Karo, Aceh, Melayu dan lain-lain. Hal ini banyak dijumpai baik di kota maupun di desa. Sudah bisa diprediksi bagaimana generasi selanjutnya ketika si anak menikah dan memiliki anak, otomatis anak keturunannya sehari-hari tidak berkomunikasi dengan bahasa daerah. Lambat laun bahasa daerah pudar, terlupakan, adat istiadat dan budaya dianggap kuno dan dipandang ketinggalan zaman. Tentu, kita tidak ingin hal itu terjadi. Jadi, seorang anak fasih dan lancar berbahasa daerah dan budaya serta adat istiadatnya sangat dipengaruhi lingkungan keluarga (ayah, ibu dan anggota keluarga) dan lingkungan masyarakat. Fenomenanya, penggunaan bahasa daerah sudah mulai luntur, jarang sekali orang tua mengajarkan bahasa daerah kepada anak-anak. Tidak hanya pendidikan utama di rumah yang sudah tidak menggunakan bahasa daerah, melainkan di lingkungan pun mulai tergeser. Desa yang kemungkinan menjaga terlestarinya bahasa daerah pun sekarang terjajah dengan pembangunan-pembangunan yang mengarah pada "meng-kota-kan desa".

Lambat laun desa pun berubah menjadi kota dengan cepatnya perkembangan. Hal ini juga berpengaruh dalam penggunaan bahasa yang menjadi peran penting dalam komunikasi. Dan ini tentu mempengaruhi fungsi bahasa; fungsi edukatif, fungsi kultural, fungsi komunikasi. Oleh karena itu, meski perubahan terus terjadi, dengan segala pencitraan, dan kemenarikan dunia. Namun apakah yang paling esensi masih bisa didapatkan pada era yang akan terus berkembang dan berubah ini? Dengan segala kecanggihan, kepintaran, kebenaran akankah kebaikan bahkan keindahan serta moral tetap terjaga , terlestarikan?

Masyarakat yang masih memegang tradisi seperti di desa maupun suku-suku tertentu terpaksa untuk ikut menjadi bagian dari perkembangan zaman yang semakin canggih dengan berbagai macam teknologinya. Di Eropa, mereka yang sudah semakin canggih dari segala teknologinya telah jenuh dengan segala rutinitas atau hiruk pikuk kesibukan. Mereka mencanangkan Slow City, dalam program kali ini ditekankan pada menjaga dan mempertahankan kondisi budaya lokal dan memajukan kekhasan di dalam kotanya (Widyaningsih, 2008). Hal tersebut sebagian di Indonesia masih dijalankan, dan sebagian besar sudah mulai ditinggalkan. Jika sudah tahu muara akhirnya bakal kembali pada seperti era Eropa saat ini yakni Slow City. Karena telah 
jenuh dan muak dengan hiruk pikuk dan kesibukan yang tiada henti. Lalu apakah Indonesia masih menghendaki menuju era serba teknologi dan meninggalkan budaya serta bahasa lokalnya. Masih mungkinkah menggunakan bahasa daerah untuk menjaga karakter generasi selanjutnya? Ketika penutur yang lebih tua dari generasi millenial telah gugur, maka tinggal generasi millenial dan generasi selanjutnya. Apakah masih relevan menggunakan bahasa daerah? Apakah berbahasa daerah akan efektif nantinya?

Satu wilayah menjadi sangat heterogen saat ini, apabila tidak kuat penjagaan terhadap ciri khasnya maka semakin luntur pula budayanya, karakternya. Kehilangan arah bukan lagi wacana, melainkan kenyataan. Kita tidak bisa menjaga bahasa daerah secara masif hanya melalui kesadaran pentingnya bahasa daerah sebagai salah satu faktor. Pembentukan karakter di tiap- tiap keluarga juga perlu untuk dikuatkan. Kita tidak memaksa semua menggunakan bahasa daerah, di luar rumah kebutuhan berkomunikasi tidak cukup diwakilkan satu bahasa saja. Melainkan multibahasa, sehingga kebutuhan akan komunikasi bisa terjalankan dengan baik. Penjaga bahasa daerah yang efektif adalah keluarga, karena sebagian besar keluarga masih dalam satu rumpun yang sama. Realitasnya telah banyak pernikahan beda suku, beda pulau bahkan beda Negara. Pernikahan seperti itu pasti mempertemukan bahasa, budaya dan kebiasaan yang berbeda.

Dari semua hal yang perlu ditekankan adalah pesan atau makna yang terkandung di dalamnya. Makna atau pesan tersebut disampaikan dengan berbagai wujud, bentuk sesuai dengan zamannya. Perwujudan yang disesuaikan dengan minat masyarakat sehingga pesan itu tersampaikan dengan baik. Namun, apa bahasa cukup dipahami hanya dengan makna atau isi pesannya saja. Apakah bahasa dasarnya dapat diwakilkan pada bahasa-bahasa lainnya? Apakah ada persamaan kata yang benar-benar dapat mewakilinya? Tentu ada perbedaan, jika memahami dengan bahasa yang berbeda dari bahasa dasarnya. Karena sebenarnya makna tidak hanya didapatkan setelah membaca ringkasan filosofi hidup orang Jawa. Melainkan makna dipelajari melalui proses kehidupan, proses perjalanan sehingga itu yang diwakilkan oleh orang terdahulu dalam kata-kata bijak yang kita kenal saat ini. Oleh karena itu, memahami makna perlu belajar dari yang dasar. Belajar dari dasar itu adalah memakai bahasa tersebut sehari-hari. Ini adalah langkah awal untuk memahami bahasa. Yang terpenting kedua adalah, setelah memahami makna seseorang mampu memberi pemahaman pada orang lain. Seperti dia memberi pemahaman pada anak usia enam tahun. Jika nantinya bahasa daerah tinggal catatan sejarah, maka itu juga tetap penting. Karena mereka yang butuh pasti mencari sampai ke akar. Jika nanti bahasa daerah sudah tak lagi terdengar, tapi tetaplah ada dokumentasinya sehingga generasi selanjutnya dapat belajar dari masa sebelumnya. Oleh karena itu bahasa daerah tetaplah penting untuk dilestarikan. 


\section{DAFTRA PUSTAKA}

Iye, R., \& Susiati, S. (2018). NILAI EDUKATIF DALAM NOVEL SEBAIT CINTA DI BAWAH LANGIT KAIRO KARYA MAHMUD JAUHARI ALI (Educative Values in

Sebait Cinta di Bawah Langit Kairo by Mahmud Jauhari Ali). Sirok Bastra, 6 (2), 185-191.

Sam, B., Iye, R., Ohoibor, M., Umanailo, M. C. B., Rusdi, M., Rahman, A. B. D., \& Hajar, I. (2019). Female Feminism in the Customary Island of Buru. Int. J. Sci. Technol. Res, 8(8), 1877-1880.

Iye, R. (2018). Tuturan emosi mahasiswa kota baubau dalam ranah demonstrasi [emotional speech of the students in baubau city in the demonstration]. TOTOBUANG, 6 (1), 125, 138.

Iye, R., \& Susiati, S. (2018). NILAI EDUKATIF DALAM NOVEL SEBAIT CINTA DI BAWAH LANGIT KAIRO KARYA MAHMUD JAUHARI ALI (Educative Values in Sebait Cinta di Bawah Langit Kairo by Mahmud Jauhari Ali). Sirok Bastra, 6 (2), 185-191.

Susiati, S., Iye, R., \& Suherman, L. O. A. (2019). Hot Potatoes Multimedia Applications in Evaluation of Indonesian Learning In SMP Students in Buru District. ELS Journal on Interdisciplinary Studies in Humanities, 2(4), 556570.

Iye, R. Jl Prof Dr HAR Basalamah No, and Namlea-Kab Buru.". TUTURAN DALAM PROSESI LAMARAN PERNIKAHAN DI TOMIA KABUPATEN WAKATOBI." Kontemporer. Bandung: PT Remaja.

Susiati, S., \& Iye, R. (2018). Kajian Geografi Bahasa dan Dialek di Sulawesi Tenggara: Analisis Dialektometri. Gramatika: Jurnal Ilmiah Kebahasaan dan Kesastraan, 6(2), 137-151.

Susiati, S., \& Iye, R. (2018). Kajian Geografi Bahasa dan Dialek di Sulawesi Tenggara: Analisis Dialektometri. Gramatika: Jurnal Ilmiah Kebahasaan dan Kesastraan. 6 (2), 137-151.

Iye, R., Susiati, S., \& Karim, K. (2020). Citra Perempuan dalam Iklan Sabun Shinzui. Sang Pencerah: Jurnal Ilmiah Universitas Muhammadiyah Buton, 6(1), 1-7.

Iye, R. (2018). Tuturan dalam Prosesi Lamaran Pernikahan di Tomia Kabupaten Wakatobi. Jurnal Totobuang, 6(2).

Iye, R. Harziko. NILAI-NILAI MORAL DALAM TOKOH UTAMA PADA NOVEL SATIN MERAH KARYA BRAHMANTO ANINDITO DAN RIE YANTI. TELAGA BAHASA,(7), 2, 195-206.

Susiati, Y. T. Risman Iye. A. Kesantunan Imperatif Bahasa Indonesia Suku Bajo Sampela: Balai Pembinaan dan Pengembangan Bahasa. 2018. Kongres Bahasa Indonesia (No. 12, pp. 1-6). Report.

UNIQBU, P. (2019). TUTURAN EMOSI MAHASISWA KOTA BAU BAU. PSP2M, T., \& Iye, R. TUTURAN EMOSI MAHASISWA KOTA BAU BAU. Umanailo, M. C. B., Hentihu, I., Umanailo, R., Nawawi, M., Pulhehe, S., Ohoibor, M., ... \& Bugis, R. I. K. I. (2018). Pemahaman Untuk Desa.

Umanailo, M. Chairul Basrun, Idrus Hentihu, Rosita Umanailo, Mansyur 
Nawawi, Sukainap Pulhehe, Mirja Ohoibor, Mohammad Faisal Sangadji et al. "Pemahaman Untuk Desa." (2018).

BURU, U. I. MODEL KOOPERATIF LEARNING TIPE STAD DALAM MENINGKATKAN KEMAMPUAN MENGAPRESIASI CERITA FIKSI DI SD NEGERI 1 NAMLEA.

Iye, R. (2018). Tuturan emosi mahasiswa kota baubau dalam ranah demonstrasi.

No, J. S. Q., Baruga, K. K., Bassalama, J. P. A., \& Si, M. PRAANGGAPAN PAMFLET SOSIALISASI PELESTARIAN LINGKUNGAN DI KABUPATEN WAKATOBI.

Djunaidi, F. G., Azwan, A. Y. T., Iye, R., \& bin Tahir, S. Z. Decks Range Gola Village Community Begun District Buton District North.

Buru, K. M. S. PENGARUH MOTIVASI BELAJAR DI SMA NEGERI 2 BURU.

No, J. S. Q., Baruga, K. K., Bassalama, J. P. A., \& Si, M. PRAANGGAPAN PAMFLET SOSIALISASI PELESTARIAN LINGKUNGAN DI KABUPATEN WAKATOBI.

BURU, U. I. MODEL KOOPERATIF LEARNING TIPE STAD DALAM MENINGKATKAN KEMAMPUAN MENGAPRESIASI CERITA FIKSI DI SD NEGERI 1 NAMLEA.

YANTI, KBADANRI. "NILAI-NILAI MORAL DALAM TOKOH UTAMA PADA NOVEL SATIN MERAH."

Buru, K. M. S. PENGARUH MOTIVASI BELAJAR DI SMA NEGERI 2 BURU.

Djunaidi, F. G., Azwan, A. Y. T., Iye, R., \& bin Tahir, S. Z. Decks Range Gola Village Community Begun District Buton District North.

Iye, R. DEIKSIS MASYARAKAT BONEGUNU KABUPATEN BUTON UTARA.

YANTI, K. NILAI-NILAI MORAL DALAM TOKOH UTAMA PADA NOVEL SATIN MERAH.

Umanailo, M. C. B. Cia-Cia Vocational Inventoryization In Buru District.

Djunaidi, F. G., Azwan, A. Y. T., Iye, R., \& bin Tahir, S. Z. Decks Range Gola Village Community Begun District Buton District North.

Buru, K. M. S. PENGARUH MOTIVASI BELAJAR DI SMA NEGERI 2 BURU.

Buru, K. M. S. PENGARUH MOTIVASI BELAJAR DI SMA NEGERI 2 BURU.

Yusdianti, A. (2020). THE REPRESENTATION VICTIMS OF VIOLENCE IN TRIBUN TIMUR ONLINE NEWS TEXT: CRITICAL DISCOURSE ANALYSIS.

BURU, U. I. MODEL KOOPERATIF LEARNING TIPE STAD DALAM MENINGKATKAN KEMAMPUAN MENGAPRESIASI CERITA FIKSI DI SD NEGERI 1 NAMLEA.

YANTI, K. NILAI-NILAI MORAL DALAM TOKOH UTAMA PADA NOVEL SATIN MERAH.

BURU, U. I. MODEL KOOPERATIF LEARNING TIPE STAD DALAM MENINGKATKAN KEMAMPUAN MENGAPRESIASI CERITA FIKSI 


\section{SD NEGERI 1 NAMLEA.}

Susiati, S. (2018). Homonim bahasa kepulauan tukang besi dialek kaledupa di kabupaten wakatobi [the homonymon of tukang besi island languange in kaledupa dialect at wakatobi regency]. Totobuang, 6 (1), 109, 123.

Susiati, S., Iye, R., \& Suherman, L. O. A. (2019). Hot Potatoes Multimedia Applications in Evaluation of Indonesian Learning In SMP Students in Buru District. ELS Journal on Interdisciplinary Studies in Humanities, 2(4), 556570.

Susiati, S., \& Iye, R. (2018). Kajian Geografi Bahasa dan Dialek di Sulawesi Tenggara: Analisis Dialektometri. Gramatika: Jurnal Ilmiah Kebahasaan dan Kesastraan, 6(2), 137-151. 